\title{
Tingkat Partisipasi Ibu Rumah Tangga tentang Sampah terhadap Pemeliharan Kebersihan Lingkungan
}

\author{
Kamaliah \\ Program Studi Teknik Lingkungan Universitas Muhammadiyah Palangkaraya \\ *email: kamaliah@umpalangkaraya.ac.id
}

\begin{abstract}
ABSTRAK. Dalam menanggulangi masalah persampahan yang disebabkan rusaknya kelestarian lingkungan dan timbulnya berbagai masalah kesehatan maka perlunya peranan atau partisipasi masyarakat terutama pengetahuan ibu-ibu rumah tangga akan pentingnya membuang sampah pada tempatnya, dan mendaur ulang sampah tersebut dijadikan kompos terutama sampah dapur. Penelitian ini bertujuan mengetahui tingkat partisipasi ibu rumah tangga tentang sampah terhadap pemeliharan kebersihan lingkungan. Penelitian ini merupakan penelitian kualitatif dengan wawancara mendalam dan dokumentasi. Hasil penelitian menunjukkan tingkat umur, pendidikan, dan pekerjaan sangat mempengaruhi pengetahuan ibu rumah tangga tentang sampah terhadap pemeliharan kebersihan lingkungan. Untuk hasil observasi dilapangan bahwa RT 01 Kelurahan Tangkiling Kecamatan Bukit Batu mendapat bantuan distribusi oleh pemerintah tempattempat bak sampah organik dan non organik, yang kegunaaannya untuk memudahkan warga dalam proses pemilahan sampah rumah tangga yang mana nantinya diambil oleh petugas sampah. Namun program yang diingikan pemerintah tersebut tidak terlaksana dengan baik, dikarenakan masyarakat terutama ibu rumah tangganya tidak melakukan pengelolaan sampah tersebut. Responden penelitian ini sebanyak 96 orang ibu rumah tangga. Ada 14 responden yang memiliki kemauan untuk terlibat dan peduli dengan sampah terhadap kebersihan lingkungannya dikarenakan sebelumnya pernah terjadi wabah penyakit DBD di RT 01, sedangkan sebagian besar responden lain menganggap penyakit tersebut biasa-biasa saja. Hasil wawancara yang diperoleh dari Lurah Tangkiling dan Ketua RT 01 adalah memeng benar adanya fasilitas tersebut namun tidak digunakan secara maksimum oleh warga Kelurahan Tangkiling terutama RT 01, sedangkan untuk hasil wawancara tentang partisipasi ibu rumah tangga tentang sampah terhadap kebersihan lingkungan memang warga tersebut kurang peduli lingkungan karena minimnya pengetahuan tentang sampah dan kebersihan.
\end{abstract}

Kata kunci: sampah, ibu rumah tangga, lingkungan

\section{PENDAHULUAN}

Sampah merupakan material sisa atau limbah baik bahan padat atau cair yang tidak dipergunakan lagi. Sampah juga merupakan masalah besar bagi negara Indonesia saat ini karena belum mendapatkan penyelesaian yang baik, hal ini disebabkan oleh faktor perubahan pola konsumsi dan gaya hidup masyarakat di daerah perkotaan maupun daerah pedesaan sehingga meningkatkan jumlah timbunan sampah ditempat pembuangan. Peningkatan jumlah sampah ini menimbulkan berbagai penyakit seperti diare, jamur dan tifus yang disebabkan oleh virus serta menurunnya 
kualitas dan terganggunya kelestarian lingkungan yang dapat memepengaruhi bahkan menjadi racun bagi mahluk hidup. Dalam menanggulangi masalah persampahan yang disebabkan rusaknya kelestarian lingkungan dan timbulnya berbagai masalah kesehatan maka perlunya peranan atau partisipasi masyarakat terutama pengetahuan ibu-ibu rumah tangga akan pentingnya membuang sampah pada tempatnya dan mendaur ulang sampah tersebut dijadikan kompos terutama sampah dapur. Oleh karena itu pentingnya pengetahuan ibu-ibu rumah tangga tentang sampah terhadap pemeliharan kebersihan lingkungan. Berdasarkan uraian diatas peneliti tertarik untuk melakukan penelitian tentang tingkat partisipasi ibu rumah tangga tentang sampah terhadap pemeliharan kebersihan lingkungan.

\section{METODE PENELITIAN}

Metode yang digunakan dalam pengumpulan data penelitian adalah observasi partisipan (participant observations), wawancara mendalam (indepth interviews) dan dokumentasi. Pelaksanaan ketiga teknik pengumpulan data tersebut tidaklah bersifat kaku akan tetapi melihat situasi yang tepat.

\section{HASIL DAN PEMBAHASAN}

Hasil penelitian tingkat partisifasi ibu rumah tangga (IRT) tentang sampah terhadap pemeliharaan kebersihan lingkungan yang diperoleh sesuai dengan karakteristik responden dapat dilihat pada tabel 1 berikut. Tabel 1. Karakteristik Responden

\begin{tabular}{ccc}
\hline Variabel & Kategori & $\begin{array}{c}\text { Jumlah } \\
\text { (orang) }\end{array}$ \\
\hline Usia & $20-30$ & 2 \\
(tahun) & $31-40$ & 6 \\
& $41-50$ & 3 \\
Pendidikan & $51-60$ & 3 \\
& SD & 8 \\
& SLTP & 3 \\
Pekerjaan & SLTA & 3 \\
& Perguruaan Tinggi & - \\
& Ibu Rumah Tangga & 9 \\
& Pedagang & 4 \\
\hline Sumber & Wirausaha & 1 \\
\hline
\end{tabular}

Sumber data: Penelitian 2018
Berdasarkan responden sesuai dengan yang berumur 20-30 tahun sebanyak 2 orang. Responden yang berumur 31-40 tahun sebanyak 6 orang, responden berumur 41-50 sebanyak 3 orang dan yang berumur 51-60 tahun sebanyak 3 orang. Adapun untuk pendidikan responden dari penelitian ini sebagai berikut : pendidikan tingkat SD berkisar 8 orang, tingkat SLTP sekitar 3 orang dan tingkat SLTA sekitar 3 orang. Kemudian untuk jenis pekerjaan responden yang paling banyak adalah ibu rumah tangga dibandingkan pedagang dan wirausahan. Dari hasil data penelitian diatas tingkat umur, tingkat pendidikan dan tingkat pekerjaan sangat mempengaruhi pengetahuan ibu rumah tangga tentang sampah terhadap kebersihan lingkungan. Adapun hasil yang diperoleh dari penelitian ini cukup baik karena ibu rumah tangga sebagian besar peduli dengan kebersihan lingkungan, dan hanya sebagian kecil ibu rumah tangga tidak peduli dengan kebersihan lingkungan. Hal ini dikarenakan ibu rumah tangga sebagian besar tidak mengetahui bahwa agama yang mereka anut memerintahkan untuk melaksanakan hidup bersih, dimana ibu rumah tangga yang mengetahui bahwa agama yang dianut memang memerintahkan untuk melaksanakan hidup bersih, namun hanya sebagian kecil dari mereka yang mengetahui hadis tentang kebersihan yang artinya ' kebersihan adalah bahagian dari iman'.

Berdasarkan hasil penelitian Fitriana 2013, mengatakan Sesuatu yang akan dilaksanakan tanpa ada kemauan/niat, maka kedepannya akan tidak tearah. Begitupun sebaliknya jika kita ingin melaksanakan sesuatu yang diawali dengan niat maka hal tersebut dengan mudah kita laksanakan, apalagi jika niat kita disertai karena Allah SWT maka seluruh kegiatan kita akan bernilai ibadah disisinya.

Hasil observasi dilapangan bahwa RT 01 Kelurahan Tangkiling Kecamatan Bukit Batu mendapat bantuan distribusi oleh pemerintah tempat-tempat bak sampah (bak sampah organik dan bak sampah non organik), yang mana kegunaaannya tempat bak sampah tersebut untuk memudahkan warga dalam proses pemilahan sampah rumah 
tangga yang mana nantinya diambil oleh petugas sampah. Namun program yang diingikan pemerintah tersebut tidak terlaksana dengan baik, dikarenakan masyarakat terutama ibu rumah tangganya tidak melakukan pengelolaan sampah yang didasari dengan adanya kemauan/niat dari ibu rumah tangga itu sendiri. Adapun untuk pelestarian lingkungan sangat penting dikarenakan pelestarian lingkungan merupakan ekologi yang tidak dapat ditawar oleh siapapun dan kapanpun. Oleh karena itu, pelestarian lingkungan tidak boleh tidak harus dilakukan oleh manusia, termasuk melakukan pengelolaan sampah. Dari hasil penelitian dilapangan yang seharusnya terlibat dipenelitian ini adalah 96 responden (ibu rumah tangga), namun 14 responden iibu rumah tangga yang hanya ada kemauan untuk terlibat dalam peduli dengan sampah terhadap kebersihan lingkungannya itupun dikarenakan sebelumnya pernah terjadi wabah penyakit DBD yang terjadi di RT 01, sedangkan sebagian besar ibu rumah tangga yang lain menganggap penyakit tersebut biasa-biasa saja. kemudian hasil wawancara yang diperoleh dari Lurah Tangkiling dan Ketua RT 01 adalah memeang benar adanya fasilitas tersebut namun tidak maksimum digunakan oleh warga Kelurahan Tangkiling terutama RT 01, sedangkan untuk hasil wawancara tentang partisipasi ibu rumah tangga tentang sampah terhadap kebersihan lingkungan memang warga tersebut kurangnya peduli lingkungan karena minimnya pengetahuan mereka tentang sampah dan kebersihan. Adapun kendala dalam penelitian ini adalah kurangnya partisipasi ibu rumah tangga terhadap kepedulian tentang sampah disekitar lingkungannya. Harapan saya dari penelitian ini untuk kedepannya nanti semoga adanya keterampilan tentang pemanfaatan sampah rumah tangga baik limbah padat maupun limbah cair.

\section{KESIMPULAN}

Kesimpulan dari hasil penelitian diatas dapat dikatakan bahwa tingkat umur, pendidikan, dan pekerjaan sangat mempengaruhi pengetahuan ibu rumah tangga tentang sampah terhadap pemeliharan kebersihan lingkungan. Adapun hasil penelitian yang di peroleh dari observasi dilapangan bahwa RT 01 Kelurahan Tangkiling Kecamatan Bukit Batu mendapat bantuan distribusi oleh pemerintah tempattempat bak sampah (bak sampah organik dan bak sampah non organik) dan hasil wawancara ke pada ibu rumah tangga cukup baik karena ibu rumah tangga sebagian besar peduli dengan kebersihan lingkungan, dan hanya sebagian kecil ibu rumah tangga tidak peduli dengan kebersihan lingkungan. sedangkan hasil wawancara yang diperoleh dari Lurah dan Ketua RT 01 adalah memang benar adanya kalau warga di RT 01 tersebut hanya sebagian besar yang peduli terhadap sampah sedangkan sebagiannya tidak peduli terhadap sampah. Untuk kendala dalam penelitian ini adalah kurangnya partisipasi ibu rumah tangga terhadap kepedulian tentang sampah disekitar lingkungannya.

\section{SARAN}

Perlu adanya memberikan keterampilan kepada warga dalam hal daur ulang dan pengomposan sampah, agar warga lebih paham bahwa ternyata sampah bias dimanfaatkan dan bias bernilai ekonomis.

\section{DAFTAR PUSTAKA}

Azkha N, Analisis Timbulan, 2006. Komposisi, dan karakteristik sampah di kota Padang. Jurnal Kesehatan Masyarakat

Fitriana, 2013. Gambaran Partisipasi Ibu Rumah Tangga dalam Pengelolaan Sampah di RW 02 Kel. Tamamaung Kec. Panakkukang Kota Makassar.

Karmila, Raden. 2012. Partisipasi Perempuan dalam Pengolalaan Sampah Rumah TAngga di RW. 02 Kel. Neglasari Kec. Cibeunying Kota Bandung.

Moleong, Lexi.2014. Metodologi Penelitian Kualitatif. Bandung : PT Remaja

Nihaya. 2012. Dampak Sampah terhadap kesehatan, 6 september 2012

Suprapto. Dampak masalah sampah terhadap kesehatan masyarakat, Jurnal Mutiara Kesehatan Indonesia, 2005. 
Moleong, Lexi.2014. Metodologi Penelitian

Kualitatif. Bandung : PT Remaja

Suharman, E.Herwan, Y.2011. pengaruh strategi penyuluhan dan motivasi pemeliharaan kesehatan lingkungan terhadap pengetahuaan ibu rumah tangga tentang sampah. Jurnal bumi lestari, 2 agustus 2011 